\title{
EFFECTS OF IFN $\gamma$ ADMINISTRATION ON ALLOGRAFT REJECTION IN GINBUNA CRUCIAN CARP
}

\author{
Yasuhiro Shibasaki, Chihiro Hatanaka, Yuta Matsuura, Ryuichiro Miyazawa, \\ Takeshi Yabu, Teruyuki Nakanishi§
}

Department of Veterinary Medicine, Nihon University, Fujisawa, Kanagawa 252-0880, Japan

\begin{abstract}
The rejection of allografts is primarily accomplished by cell-mediated immunity including $\mathrm{T}$ cells and IFN $\gamma$ in mammals. Recently, we identified four IFN $\gamma$ isoforms with antiviral activities in ginbuna crucian carp. In fish, however, the roles of IFN $\gamma$ isoforms in cell-mediated immunity remain unknown. Here we investigate the effects of administration of recombinant ginbuna IFN $\gamma(\operatorname{rgIFN} \gamma)$ isoforms in scale allograft rejection. IFN $\gamma$ rel 1 showed significantly higher expression at 5 days after allografting, while significant changes were not observed in other isoforms. Administration of rgIFN $\gamma$ rel 1 but not $\operatorname{rgIFN} \gamma \mathrm{rel} 2$ nor $\operatorname{rgIFN} \gamma 2$ enhanced the allograft rejection. The number of $\mathrm{CD}^{+}$and $\mathrm{CD} 8 \alpha^{+}$cells in grafted scales and surrounding epidermis increased at an early stage of rejection, while that of $\operatorname{sigM}{ }^{+}$cells increased at day 0 and day 5 in rgIFN $\gamma$ rel 1 administrated group. Accumulation of $\mathrm{CD} 8 \alpha^{+} \mathrm{T}$ cells from distal to medial epidermis of grafted scales was accelerated in rgIFN $\gamma$ rel 1 administrated group. Interestingly, mRNA expression of IFN $\gamma 1$ and IFN $\gamma 2$ was significantly up-regulated after $\operatorname{rgIFN} \gamma$ rel 1 administration, while that of IFN $\gamma$ rel 1 and IFN $\gamma$ rel 2 was not. Expression of granzyme was significantly higher at day 2 in rgIFN $\gamma$ rel 1 administrated group, while that of Perforin 1 and 3 was not. These results suggest that the administration of rgIFN $\gamma$ rel 1 induced the accumulation of $\mathrm{T}$ cell subsets at the allograft site and the secretion of effector molecules resulting in the promotion of allograft rejection. Present results also suggest the differential contribution of four IFN $\gamma$ isoforms to allograft rejection.
\end{abstract}

\section{KEYWORDS}

IFN gamma; allograft rejection; CD4; CD8; teleost

§Corresponding author. Tel.: +81 466843383; Fax: +81466843380

E-mail address: nakanishi.teruyuki@nihon-u.ac.jp 